\title{
MILITARY MOBILITY IN THE EUROPEAN THEATRE
}

\author{
Dragoș-Mihai Păunescu ${ }^{1}$ \\ "Carol I" National Defence University
}

\begin{abstract}
To ensure its defense and deterrence posture, NATO has to prove the ability to quickly deploy, reinforce and sustain its forces across the entire SACEUR Area of Responsibility. To ensure the end-state of free deployment of forces across Europe, the Alliance identified the need to abolish legal and administrative barriers and to improve the infrastructure status and transportations capacity.

Both NATO and the European Union recognized the military mobility deficiencies as a strategic vulnerability for Europe in case of a peer-to-peer conflict scenario.
\end{abstract}

Keywords: NATO; European Union; Eastern Flank; military mobility; deployment; sustainment.

\section{INTRODUCTION}

All the emplaced and the foreseen deterrence and defense measures are depending on the Alliance ability to quickly deploy its forces in the required areas, to integrate them in assigned Area of Responsibility (AoR) and to properly sustain and reinforce them. For an effective deterrence posture, against a peer adversary, NATO has to look back and to reassess the lessons identified and learned during the Cold War.

In that period, the allied effort was directed to Central Europe with massive conventional forces deployed forward, in response to Moscow's threat. The regional responsibilities were clearly defined and assigned to field commanders that were already aware about the future boundaries, neighboring formations and the arrangement done for national, multinational and host nation support. Also, there were in place detailed plans on Rear Area engagements as infrastructure, war stocks, strategic lift capacity, and sustainment procedures.

As for nowadays situation, we can identify different types of barriers for military deployment and operations. Primarily, the physical, legal and administrative obstacles are in relation to the existing transportation infrastructure of the European territory and with the border crossing procedures. In 2017, during a US led exercise that simulated an airborne operation designated to repel an adversary force that violated the territorial integrity of a NATO member, the helicopter of General Ben Hodges, US Army Europe commander, flying from Hungary, was diverted from its planned course to accomplish border crossing procedures in Romania. (European Army Center 2021) Such administrative procedures, as passport and customs checks, but also infrastructure caveats and legal constrains constitute typical routine in Europe and pose a significant risk to military speed and efficiency.

\section{MOBILITY AND SUSTAINMENT CHALLENGES}

Through the adaptation process and the Deterrence and Defense of the Euro-Atlantic area (DDA) posture, NATO is committed to reach again the peer-to-peer deterrence capabilities. In current security environment, the readiness and the ability to quickly deploy and effect are some of the most relevant characteristics of forces. In this spirit, NATO looks for reducing the obstacles to military movement into and across Europe, and for an efficient sustainment flow for its forces.

In conjunction with the implementation of Joint Support and Enabling Command (JSEC) in Ulm, starting 2018, NATO members took further steps to ensure allied forces can be mobilized and

\footnotetext{
${ }^{1}$ Corresponding author: Dragos.paunescu@lc.nato.int
} 
deployed faster, and to improve the forces military mobility by land, air, and sea. At the Brussels Summit in July 2018, the Alliance agreed upon an "enablement plan", in order to enhance Command and Control (C2) capabilities and to increase transport capabilities in support of military mobility.

NATO tested its ability to move military assets between European countries during large military exercise that involved force deployments, overloads of the transportation infrastructure and logistic hubs, joint training and integrations of units. Exercise series like Trident Juncture, Brilliant Jump or Noble Jump each represent a massive logistical challenge that tests the ability of NATO members to deploy a fighting force to wherever it is needed. The practiced deployments are focused on the NATO Response Force (NRF) elements with high readiness and are closely coordinated with local NATO headquarters and national authorities from the receiving nations.

The primary objective of this type of training events is to maintain the readiness of Very High Readiness Joint Task Force (VJTF) forces, to evaluate their ability to rapidly deploy and to enhance the logistic interoperability of allies and partners. However, through NATO exercises relevant lessons regarding legal and administrative procedures are identified, information regarding the infrastructure status is collected and the local logistic hubs' capacity to deal with the burden of receiving large volumes of troops and equipment is also tested.

In April 2020, the International Centre for Defense and Security published a report signed by the former LANDCOM and US Army Europe commander Ben Hodges together with Tony Lawrence and Ray Wojcik, regarding the military mobility in Europe. "Until Something Moves: Reinforcing the Baltic Region in Crisis and War" study recommends that NATO and the EU should continue to work together to "reduce potential barriers to movement created by cross-border and in-country movement regulations, customs and taxation requirements, and other administrative and legislative procedures". (Ben Hodges 2021)

At the EU level, according to the Council decisions of June 25, 2018, the European Commission launched, in collaboration with European Defense Agency, the development of the "Action Plan on Military Mobility" that intends to soothe and standardize cross-border procedures for military personnel and equipment. The EU is recognizing that the military mobility represents a "strategic weakness in European defense cooperation" and "in the event of an unpredictable crisis at any EU border, military personnel and equipment must be able to move rapidly across the territory. Currently, training and the movement of military assets across the continent is severely hampered by the lack of appropriate infrastructure and cumbersome customs procedures." (EU Parliament 2021)

After 2014, the relevance of the mobility projects increased dramatically for the Eastern Flank's NATO members. Romania's 2020 White paper on defense, also underlines the importance of the military mobility and states that "promoting projects on the interconnection of transport routes, in the context of the commitments on military mobility undertaken in the framework of NATO and the EU" (R. W. defence 2020 ) is a major objective of Bucharest.

The challenges of NATO's Eastern Flank and the critical importance of military mobility were regularly promoted by Romania inside both Western organizations. Among other central figures as the head of the EU Military Committee, General Claudio Graziano, the former Commander of LANDCOM and US Army Europe presented his view on military mobility during "Military Mobility and Supporting Infrastructure. A New Challenge to EU and NATO" conference. The 2019 event, was organized by the New Strategy Centre and German Marshall Fund Romania in association with the Ministry of Defense of Romania, represented a local platform for discussions regarding the abolishment of procedural and legal barriers, infrastructure improvement and better coordination of the activities in support of military operations in the Eastern Flank.

In March 2020 when the economic difficulties generated by COVID-19 pandemic hampered the resource allocation for projects such as European Defense Fund and the Military Mobility initiative, the foreign ministers of the states belonging to Bucharest Nine Format protested. Poland, Romania, Latvia and Lithuania, EU and NATO members, mentioned in a joint letter that Brussels' budget cuttings could affect EU ambitions in the "military mobility" programme. The project was considered one of the Commission priorities and contained measures to move troops and equipment efficiently across Europe in the event of a conflict in the East. 
The Bucharest Nine demand came as a technical document was previously realest by EU Commission in which it was revealed the EU's 2021-2027 budget proposal to drastically reduce the funding for the military mobility programme. In these conditions, without a common funding, the EU countries supposed to exclusively allocate national funding for updating bridges, roads and rail networks to ensure military responsiveness in case of a conflict with Russia. Following negotiations, the bloc's defense plans were assumed by Brussels and the Military Mobility initiative is set to obtain 1.5 billion EUR in the seven-year plan starting 2021. (Sprenger 2021)

\section{INFRASTRUCTURE GAPS}

During the Cold War, both security blocks developed a deep knowledge, translated into capabilities, on the infrastructure requirements for large military operations and strategic and operational deployments of forces and equipment. Nowadays much of that knowledge has been lost and the old infrastructure degraded. Moreover, the majority of present-day maps do not offer even basic figures regarding the infrastructure characteristics.

After the Cold War, due to the changes in the security environment and a shift in NATO's focus from deterrence to out-of-area-operations, roads, bridges and rail networks across Europe were not built with military considerations in mind, and cannot sustain use by heavy military equipment.

Infrastructure represents a major factor within high-level keystone considerations such as strategic advance planning and the Concept for Deterrence and Defense of the Euro-Atlantic Area (DDA). Assessing the impact of infrastructure deficiencies on NATO force deployments and operations is a priority for both NATO and EU, but the Alliance is lacking the economic leverage to act on its own to mitigate the identified gaps.

The development of infrastructure became an inherent part of readiness and reinforcement initiatives and relevant progress has been made to integrate infrastructure into the overall process, starting with strategic level planning.

Infrastructure is a cross functional approach in support of planning, conducting and sustainment for operations, and it constitutes a significant aspect of the physical operating environment. Starting 2014, after decades when the military infrastructure has been neglected and was only treated at the tactical level (construction), the return to the collective defense concerns has led to readiness and reinforcement initiatives that often have to rely on an inadequate infrastructure. Because these initiatives require an AOR prepared to the level of ambition and specific timelines, the focus has increased on NATO territory enablement and on infrastructure investments.

The transport infrastructure deficiencies, identified by NATO planners, are ranging from limitations generated by the weight capacity of the road surface, bridges capacity and railway traffic restrains. For strategic and operational deployment of heavy equipment, the railway system is the optimal transport choice, but the investments in this sector were very limited in Eastern Europe generating a significant decrease of its transport capacity. The road network was developed without considering the military needs and transport standards and has as the main restrain the capacity of bridges which cannot ensure the passage of the heaviest armour.

These infrastructure capacity challenges can be solved on long term through standardization and expensive investment programs, but a short-term mitigation option could be the creation of accurate databases with infrastructure specifications and the acquisition of indispensable equipment such as rail wagons with appropriate carrying capacity and road semi-trailer carriers. For deploying and sustaining operations, NATO is relaying on Logistics Functional Services (LOGFAS), a software that enables logistics planners at the strategic, operational, and tactical levels to effectively plan for movement and sustainment of personnel and equipment. For operations, the LOFAS data base creation, synchronization and deconfliction is the responsibility of SJLSG HQ. The SJLSG Allied Movement Coordination Centre (AMCC), the Major NATO Command (MNC) agency for management of strategic movements is providing the validation and supervision for this task, but nations are often reluctant to share all relevant details, especially in term of infrastructure capabilities.

NATO efforts, in conjunction with the European Union, are directed to enhance military mobility. Areas of cooperation include coordination of military requirements, customs and border- 
crossing legislation, regulations and procedures, and transport infrastructure. NATO members, together with EU, are working to ensure that the required legislation and procedures are in place to mobilize and move the forces across borders rapidly, to enhance Command, Control and Communications (C3), and to increase the Alliance's capabilities and capacities, including by upgrading the infrastructure across Europe. As part of these broader efforts, in October 2019, NATO, in close cooperation with EUROCONTROL, (EUROCONTROL civil-military organisation) established the Rapid Air Mobility Mechanism, which allows Allied aircraft to move across Europe with priority handling by Air Traffic Control in Europe.

Within the framework of the European Union military Mobility Concept, parameters for EU infrastructure work have been established, allowing nations to organize national infrastructure planning and to implement military considerations required by NATO. The next step, which is already initiated, is the Strategic Infrastructure Master Planning that should establish a connection of infrastructure to defense planning. This would support the allies at the political level in their determination to what degree infrastructure requirements should be included in future capability targets.

All these projects will widen the current purely force focused defense planning process to include infrastructure. As one of the supporting pillars, infrastructure assessment is further being developed. (Conference 2021) This allows for assessing the capability of existing infrastructure in support of operations. Focused at NATO operational and national level, the infrastructure assessment provides input for gap analysis in support of Strategic Infrastructure Master Planning.

\section{CONCLUSIONS}

In order to increase Europe strategic independence both NATO and EU should continue working in conjunction to re-establish capabilities, to improve the ability to reinforce and resupply across the continent.

The road and rail networks should be set to be able to handle heavy military equipment, investments are needs to prepare the internal waterways and also sea and air ports that connect not only different European region, but the EU with its oversea partners. Being a costly long-term process, achieving the required level of mobility for military operations should be complemented with short and medium term security mitigations measures.

To address deployment, reinforcement and sustainment challenges for the NATO's Eastern Flank, regional initiatives have been emplaced to increase cooperation and to preposition forces, equipment and stocks. All these incoming resources would be under the $\mathrm{C} 2$ of regional multinational headquarters that will address security threats by coordinating the host receiving nations' efforts to the ones of sending nations.

\section{REFERENCES}

*** On the way towards a true military mobility. 2021. Brussels - European Army Interoperability Center, accessed on February 10, at: Military-Schengen-Towards-a-true-Military-Mobility-1.pdf (finabel.org)

Hodges, Ben, Lawrence, Tony, Wojcik, Ray. 2021. Until Something Moves: Reinforcing the Baltic Region in Crisis and War, accessed on February 10, at: https://icds.ee/en/until-somethingmoves-reinforcing-the-baltic-region-in-crisis-and-war/

European Parliament. 2021. Military mobility, accessed on February 10, at: https://www.europarl.europa.eu/RegData/etudes/ATAG/2019/635570/EPRS_ATA(2019) 635570_EN.pdf 
${ }^{* * *}$ Romania's White paper on defence. 2020. Bucharest: 23.

Sprenger, Sebastian. 2021. The European Union's defense ambitions are still showing signs of life, accessed on February 12, at: https://www.defensenews.com/global/europe/2020/05/29/theeuropean-unions-defense-ambitions-are-still-showing-signs-of-life/.

EUROCONTROL is a pan-European, civil-military organisation dedicated to supporting European aviation.

*** NATO Land Engineers Conference. 2021. Accessed on February 12, at: https://lc.nato.int/mediacenter/news-archive/2016/nato-land-engineers-conference-nlec-and-critical-infrastructureassessment-seminar 